\title{
Inventarisasi Emisi Pencemar Kriteria dan Gas Rumah Kaca dari Sektor Transportasi On- Road di Kota Bandung menggunakan Model International Vehicle Emissions (IVE)
}

\section{BILLY YOGA DEWANTO ${ }^{1}$, MILA DIRGAWATI1, DIDIN AGUSTIAN PERMADI ${ }^{1}$}

1. Jurusan Teknik Lingkungan, Fakultas Teknik Sipil dan Perencanaan, Institut Teknologi Nasional, Bandung

Email : billyyogadwt@gmail.com

\begin{abstract}
ABSTRAK
Perkembangan Kota Bandung berimplikasi terhadap pesatnya pertumbuhan aktivitas transportasi. Akibatnya, terjadi peningkatan emisi kendaraan bermotor secara kontinu. Penelitian ini bertujuan untuk mengestimasi beban emisi pencemar kriteria dan gas rumah kaca dari sektor transportasi on-road di Kota Bandung, khususnya untuk truk. Estimasi beban emisi diperoleh dari hasil simulasi model IVE untuk menghasilkan faktor emisi lokal komposit disertai dengan pembaruan pada jumlah registrasi seluruh jenis kendaraan di Kota Bandung. Beban emisi total tahunan paling dominan yang dihasilkan dari aktivitas transportasi di Kota Bandung tahun 2019 yakni 5.286.612,81 ton/tahun (94,48\%) $\mathrm{CO}_{2} ; 254.378,9$ ton/tahun (4,55\%) CO; dan 35.501,65 ton/tahun (0,63\%) $N O_{x}$ dengan kontribusi terbesar berasal dari $(98,9 \%)$ emisi running. Moda transportasi yang menyumbang proporsi emisi total terbesar berasal dari 43,4\% mobil pribadi, $27,8 \%$ truk, 17,1\% sepeda motor, dan 10,1\% berasal dari bus.
\end{abstract}

Kata kunci: Aktivitas Transportasi, Model International Vehicle Emissions (IVE), Beban Emisi

\begin{abstract}
The development of Bandung city has affected the level of community mobilization needs, which has implications for the rapid growth of transportation activities. As a result, an increase in motor vehicle emissions continues to have an impact on decreasing air quality in Bandung city. This study aims to estimate emission load of criteria pollutant and greenhouse gases from the on-road transportation sector, especially for trucks. Emission load estimates are obtained from the results of the IVE model simulation to generate composite local emission factors accompanied by updates on current registration numbers of vehicles in Bandung city. The most dominant total annual emission load generated from all type of fleets in Bandung city in 2019 was 5,286,612.81 tons/year (94.48\%) $\mathrm{CO}_{2} ; 254,378.9$ tons/year (4.55\%) CO; and $35,501.65$ tons/year $(0.63 \%) N_{x}$, with the largest contribution coming from running emissions. Major transportation modes that accounted for the largest proportion of total emissions came from $43.4 \%$ of private cars, $27.8 \%$ of trucks, $17.1 \%$ of motorbikes and $10.1 \%$ of buses.
\end{abstract}

Keywords: Transportation Activities, International Vehicle Emissions (IVE) Model, Emission Load 


\section{PENDAHULUAN}

Predikat Kota Bandung sebagai kawasan strategis nasional orde I menjadi faktor pendorong perkembangan Kota Bandung sebagai kawasan ekonomi, sehingga memicu peningkatan taraf kebutuhan masyarakat akan mobilitas yang fleksibel. Hal tersebut berimplikasi terhadap peningkatan aktivitas transportasi di Kota Bandung melalui masifnya pertumbuhan kendaraan bermotor mencapai $11 \%$ setiap tahunnya, dengan indikasi semakin tingginya kepadatan lalu lintas yang didominasi oleh $98 \%$ kendaraan pribadi dan hanya $2 \%$ kendaraan umum (BPS, 2018; ADB, 2019).

Namun, perkembangan transportasi tersebut tidak sebanding dengan upaya pembaharuan teknologi gas buang kendaraan bermotor berdasarkan standar emisi Euro. Berdasarkan Oanh dkk (2018), penerapan teknologi gas buang pre-euro masih ditemukan pada sejumlah kendaraan bermotor di Kota Bandung seperti : angkot 52,9\%, taksi 27,8\%, mobil pribadi $21,5 \%$, bus $18,1 \%$ dan $1,9 \%$ sepeda motor. Sedangkan, truk belum teridentifikasi dan berpotensi masih menerapkan pre-euro dalam skala yang besar. Buruknya efisiensi reduksi emisi gas buang pre-euro sebesar $75 \%$ dibandingkan euro 2, menjadi salah satu faktor krusial penyumbang emisi gas rumah kaca dengan komposisi $2.680 \mathrm{Gg} / \operatorname{tahun}(92,16 \%)$ emisi $\mathrm{CO}_{2}$, dan $5,8 \mathrm{Gg} /$ tahun $(0,2 \%)$ emisi $\mathrm{CH}_{4}$ dan pencemar kriteria dengan $168 \mathrm{Gg} /$ tahun $(5,77 \%)$ emisi $\mathrm{CO}, 16 \mathrm{Gg} /$ tahun $(0,55 \%) \mathrm{NO}_{\mathrm{x}}$ terhadap penurunan kualitas udara ambien di Kota Bandung (Oanh dkk., 2018).

Fenomena tersebut menjadi urgensi diperlukannya upaya pengelolaan kualitas udara di Kota Bandung melalui inventarisasi emisi untuk mengkuantifikasi beban emisi dari kendaraan bermotor, khususnya truk yang potensi emisinya belum teridentifikasi pada penelitian terdahulu oleh Oanh dkk (2018). Pada penelitian ini metode yang digunakan untuk mengestimasikan beban emisi kendaraan bermotor di Kota Bandung sama dengan penelitian terdahulu, yakni model International Vehicle Emissions (IVE). Model ini secara khusus mempertimbangkan variabel teknis seperti faktor emisi lokal, pola berkendara aktual, dan distribusi teknologi yang relevan dengan kondisi transportasi di wilayah tertentu dalam mengestimasikan beban emisinya (Davis, 2008).

\section{METODOLOGI}

\subsection{Lokasi Penelitian}

Penelitian ini dilakukan di wilayah pusat (urban) dan pinggiran (suburban) Kota Bandung. Wilayah urban direpresentasikan melalui terdapatnya kegiatan pemerintahan dan komersil, sebaliknya untuk wilayah suburban. Setiap wilayah tersebut harus dilintasi oleh ruas jalan utama yang mewakili 3 (tiga) kategori jalan diantaranya jalan tollway, jalan arterial dan jalan residential dengan tujuan untuk mendapatkan volume kendaraan bermotor harian Kota Bandung yang representatif berdasarkan fungsi jalan (Davis, 2008). Adapun rincian pemetaan lokasi penelitian dapat dilihat pada Tabel 1 sebagai berikut.

Tabel 1. Lokasi Penelitian

\begin{tabular}{|c|c|c|}
\hline Wilayah & Jenis Jalan & Lokasi Penelitian \\
\hline \multirow{3}{*}{$\begin{array}{l}\text { Pusat Kota Bandung } \\
\text { (Urban) }\end{array}$} & Tollway & Pasteur \\
\hline & Arterial & Jl. PHH. Mustopha \\
\hline & Residential & Jl. Purwakarta (Antapani) \\
\hline \multirow{3}{*}{$\begin{array}{l}\text { Pinggiran Kota Bandung } \\
\text { (Suburban) }\end{array}$} & Tollway & Pasir Koja \\
\hline & Arterial & Jl. Soekarno-Hatta \\
\hline & Residential & Jl. Rancabolang (Margahayu) \\
\hline
\end{tabular}

Sumber : Hasil Analisis, 2019 


\subsection{Pengumpulan Data}

Pada penelitian ini terdapat 4 (empat) jenis data utama yang akan dikumpulkan antara lain :

A. Registrasi Kendaraan Bermotor Kota Bandung

Data ini akan digunakan dalam penentuan jumlah sampel truk dalam proses identifikasi distribusi teknologi, pembaharuan data beban emisi penelitian terdahulu untuk jenis kendaraan bermotor lainnya (terkecuali truk), dan estimasi beban emisi untuk truk di Kota Bandung. Rincian data selengkapnya dapat dilihat pada Tabel $\mathbf{2}$ dibawah ini.

Tabel 2. Jumlah Registrasi Kendaraan Bermotor Kota Bandung Tahun 2018

\begin{tabular}{ccccc}
\hline Jenis Kendaraan & $\begin{array}{c}\text { SAMSAT I } \\
\text { Pajajaran }\end{array}$ & $\begin{array}{c}\text { SAMSAT II } \\
\text { Kawaluyaan }\end{array}$ & $\begin{array}{c}\text { SAMSAT III } \\
\text { Soetta }\end{array}$ & Total (unit) \\
\hline Sepeda Motor & 491.158 & 459.130 & 378.699 & 1.328 .783 \\
\hline Mobil Pribadi & 122.226 & 141.303 & 124.891 & 388.420 \\
\hline Bus & 2.029 & 3.118 & 1.601 & 6.748 \\
\hline Truk & 31.876 & 24.657 & 19.565 & 76.098 \\
\hline Angkot & & 5.552 & & 5.552 \\
\hline Taksi & & 1.906 & & 1.906
\end{tabular}

Sumber : BPS Kota Bandung, 2018

B. Pengukuran Volume Kendaraan Bermotor Harian

Pengukuran ini dilakukan selama 12 jam pada 4 periode waktu jam puncak meliputi :

a. Puncak Pagi (06.00 AM - 08.00 AM)

b. Puncak Siang (11.00 AM - 13.00 PM)

c. Puncak Sore (16.00 PM - 18.00 PM)

d. Puncak Malam (18.00 PM - 20.00 PM)

C. Identifikasi Distribusi Teknologi Truk

Tahap ini dilakukan dengan mengumpulkan sampel truk berdasarkan metode slovin (error $10 \%$ ) dengan jumlah sampel sebesar 100 truk. Selanjutnya, pengumpulan data dilakukan menggunakan pendekatan parking lot survey melalui interview secara langsung kepada responden di Balai Inspeksi Kendaraan Bemotor Dinas Perhubungan Kota Bandung.

D. Tracking Aktivitas Berkendara Harian Truk

Tracking ini bertujuan merekam informasi (data) perubahan kecepatan, waktu tempuh dan waktu tundaan (soak time) truk dalam sehari. Informasi tersebut akan digunakan dalam analisis nilai Vehicle Specific Power (VSP) dan Engine Stress untuk keperluan estimasi beban emisi model IVE. Pengumpulan data dilakukan dengan memasang alat GlobalSat DG-100 GPS Data Loggers pada 2 jenis truk meliputi niaga dan pribadi selama 24 jam di hari kerja (weekday) dan akhir pekan (weekend).

\subsection{Volume Kendaraan Bermotor Harian}

Informasi terkait akumulasi volume kendaraan bermotor (khususnya truk) harian Kota Bandung akan digunakan dalam analisis temporal emisi sektor transportasi on-road dan aktualisasi komponen data jumlah start-up dan jarak tempuh harian truk yang dipertimbangkan dalam estimasi beban emisi model IVE.

\subsection{Fleet Index Truk}

Informasi teknologi setiap truk akan dikelompokkan berdasarkan urutan komponen teknologi yang telah ditentukan oleh model IVE (Davis, 2008). Pengelompokkan teknologi ini digunakan untuk menentukan fleet index yang bertujuan untuk memudahkan proses input data distribusi teknologi truk pada menu fleet dalam model IVE (lihat Gambar 1). 


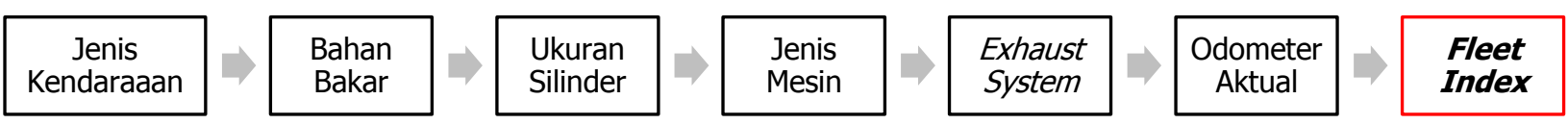

Gambar 1. Mekanisme Penentuan Fleet Index (Sumber: Davis, 2008)

\subsection{Perhitungan Vehicle Kilometer Travelled (VKT) Harian Truk}

Vehicle Kilometer Travelled (VKT) merupakan data panjang perjalanan harian truk yang diperoleh dari hasil analisis statistik regresi linier antara odometer dengan umur aktual aktual di Kota Bandung. Hasil regresi linier diolah menggunakan persamaan sebagai berikut :

\section{VKT = (Jarak Tempuh Odometer)/(Umur Rerata Truk x 365 hari)}

Selanjutnya, nilai VKT harian truk yang dihasilkan akan digunakan sebagai komponen data utama dalam mengestimasikan beban emisi running model IVE.

\subsection{Perhitungan Vehicle Specific Power (VSP) dan Engine Stress Truk}

Pengujian kecepatan dan waktu tempuh harian truk Kota Bandung akan digunakan sebagai komponen data untuk mendapatkan nilai Vehicle Specific Power (VSP) dan Engine Stress truk melalui persamaan sebagai berikut :

$$
\text { VSP }=v[1.1 a+9.81(\operatorname{atan}(\sin (\operatorname{grade})))+0.132]+0.000302 v^{3}
$$

\section{Keterangan:}

$\mathrm{v}=$ Kecepatan kendaraan $(\mathrm{m} / \mathrm{s})$

Koefisien gravitasi $(9,81)$

$\mathrm{a}=$ Akselerasi kendaraan $(\mathrm{m} / \mathrm{s} 2)$

Koefisien rolling resistance $(0,132)$

$\mathrm{H}=$ Altitude jalan $(\mathrm{m})$

Koefisien tarik $(0,000302)$

\section{Engine Stress $=$ RPMIndex $+(0,08$ ton $/ \mathrm{kW}) \times$ Average}

\section{Keterangan:}

Pre-average Power $=$ Average

VSP $\mathrm{t}=5$ dektik $\mathrm{s} / \mathrm{d} \mathrm{t}=25$ detik (kW/ton)

Model IVE menggabungkan 20 kategori VSP yang dikombinasikan dengan 3 (tiga) mode engine stress (low, medium dan high stress) untuk menghasilkan 60 nilai bin yang mewakili distribusi pola berkendara harian. Nilai bin yang dihasilkan digunakan untuk input data menu location dalam model IVE.

\subsection{Model International Vehicle Emissions (IVE)}

\subsubsection{Input Data Model IVE}

Proses input data yang dibutuhkan dalam estimasi beban emisi model IVE untuk truk melalui 2 (dua) tahapan diantaranya :

\section{A. Fleet Input Data}

Menu fleet digunakan untuk input informasi terkait karakteristik distribusi teknologi (fleet index) truk di Kota Bandung.

\section{B. Location Input Data}

Menu location digunakan untuk input informasi terkait karakteristik aktivitas berkendara harian truk di Kota Bandung. Rincian komponen data yang diinput meliputi aktualisasi jumlah start-up dan jarak tempuh harian terhadap volume truk harian, kondisi lingkungan, karakteristik bahan bakar, distribusi soak time, dan distribusi nilai bin VSP/engine stress.

\subsubsection{Simulasi Model IVE}

Simulasi ini bertujuan untuk mendapatkan faktor emisi lokal komposit truk untuk setiap jenis polutan yang diteliti berdasarkan pertimbangan informasi karakteristik distribusi teknologi dan aktivitas berkendara harian dari setiap jenis truk tertentu di Kota Bandung. Faktor emisi tersebut merupakan hasil komposit antara hari kerja dan hari libur pada kondisi operasional 
running dan start-up. Sedangkan, pada penelitian ini faktor emisi lokal Kota Bandung untuk jenis kendaraan bermotor lainnya diperoleh dari hasil penelitian Kim Oanh dkk. (2018) pada Tabel 3 dibawah ini.

Tabel 3. Faktor Emisi Kendaraan Bermotor di Kota Bandung

\begin{tabular}{|c|c|c|c|c|c|c|c|c|c|c|}
\hline \multirow{3}{*}{ Polutan } & \multicolumn{10}{|c|}{ Faktor Emisi Komposit } \\
\hline & \multicolumn{2}{|c|}{ Sepeda Motor } & \multicolumn{2}{|c|}{ Mobil Pribadi } & \multicolumn{2}{|c|}{ Angkot } & \multicolumn{2}{|c|}{ Taksi } & \multicolumn{2}{|c|}{ Bus } \\
\hline & $\begin{array}{c}\text { Start } \\
\text { (g/start) }\end{array}$ & $\begin{array}{l}\text { Running } \\
(\mathrm{g} / \mathrm{km})\end{array}$ & $\begin{array}{c}\text { Start } \\
\text { (g/start) }\end{array}$ & $\begin{array}{l}\text { Running } \\
(\mathrm{g} / \mathrm{km})\end{array}$ & $\begin{array}{c}\text { Start } \\
\text { (g/start) }\end{array}$ & $\begin{array}{l}\text { Running } \\
(\mathrm{g} / \mathrm{km})\end{array}$ & $\begin{array}{c}\text { Start } \\
\text { (g/start) }\end{array}$ & $\begin{array}{l}\text { Running } \\
(\mathrm{g} / \mathrm{km})\end{array}$ & $\begin{array}{c}\text { Start } \\
\text { (g/start) }\end{array}$ & $\begin{array}{c}\text { Running } \\
(\mathrm{g} / \mathrm{km})\end{array}$ \\
\hline CO & 4.43 & 6.39 & 17.4 & 22.4 & 7.76 & 25.1 & 14 & 22.9 & 0.45 & 5.33 \\
\hline $\mathrm{NO}_{\mathrm{x}}$ & 0.39 & 0.17 & 0.67 & 1.79 & 0.31 & 1.92 & 0.83 & 1.09 & 1.12 & 23.9 \\
\hline $\mathrm{SO}_{\mathrm{x}}$ & 0.0002 & 0.01 & 0.0036 & 0.054 & 0.0015 & 0.059 & 0.003 & 0.03 & 0.014 & 0.65 \\
\hline PM & 0.04 & 0.03 & 0.05 & 0.04 & 0.02 & 0.04 & 0.01 & 0.01 & 1.82 & 4.67 \\
\hline $\mathrm{CO}_{2}$ & 1.86 & 69.4 & 11.9 & 434 & 4.79 & 406 & 8.93 & 288 & 37.8 & 1789 \\
\hline $\mathrm{N}_{2} \mathrm{O}$ & 0.0005 & 0 & 0.004 & 0.01 & 0.001 & 0.01 & 0.002 & 0.01 & 0.01 & 0.09 \\
\hline $\mathrm{CH}_{4}$ & 0.0005 & 0.41 & 0.42 & 0.43 & 0.15 & 0.58 & 0.28 & 0.54 & 0 & 0 \\
\hline
\end{tabular}

Sumber : Oanh dkk. (2018)

Selanjutnya, faktor emisi komposit tersebut akan digunakan dalam proses estimasi beban emisi sektor transportasi on-road khususnya truk.

\subsubsection{Estimasi Beban Emisi Model IVE}

Berdasarkan Davis (2008), model IVE dapat mengestimasikan beban emisi kendaraan bermotor khususnya truk pada 2 (dua) kondisi operasional sebagai berikut :

A. Beban Emisi Start-up ( $\left.\mathrm{Q}_{\text {start }}\right)$

Emisi start-up merupakan pencemar yang dihasilkan dari pembakaran internal mesin ketika aktivasi kendaraan setelah kondisi idling.

$$
\mathbf{Q}_{\text {start }}=\mathrm{FE}_{\text {start }} \times \text { Jumlah start-up harian x Populasi kendaraan }
$$

\section{Keterangan :}

$\mathrm{FE}_{\text {start }}=$ Faktor emisi start-up ( $\left.\mathrm{g} / \mathrm{start}\right)$

Distribusi Start-up = Jumlah start-up per hari (start/hari)

Populasi $=$ Registrasi kendaraan bermotor di Kota Bandung tahun 2018

B. Beban Emisi Running (Q Q

Emisi running merupakan pencemar yang dihasilkan dari pembakaran internal mesin selama operasional kendaraan bermotor.

$$
Q_{\text {running }}=\mathrm{FE}_{\text {running }} \times \text { VKT } \times \text { Populasi kendaraan }
$$

\section{Keterangan :}

$\mathrm{FE}_{\text {running }}=$ Faktor emisi running $(\mathrm{g} / \mathrm{km})$

VKT $=$ Vehicle kilometer travelled $(\mathrm{km} /$ hari $)$

Populasi $=$ Registrasi kendaraan bermotor di Kota Bandung tahun 2018

\section{HASIL DAN PEMBAHASAN}

\subsection{Volume Kendaraan Bermotor Harian}

Pengukuran volume harian untuk 6 jenis kendaraan bermotor dilaksanakan pada 6 titik ruas jalan berdasarkan kategorinya di Kota Bandung. Adapun hasil pengukuran tersebut dapat dilihat pada Gambar $\mathbf{2 a}$ dan $\mathbf{2 b}$ berikut. 

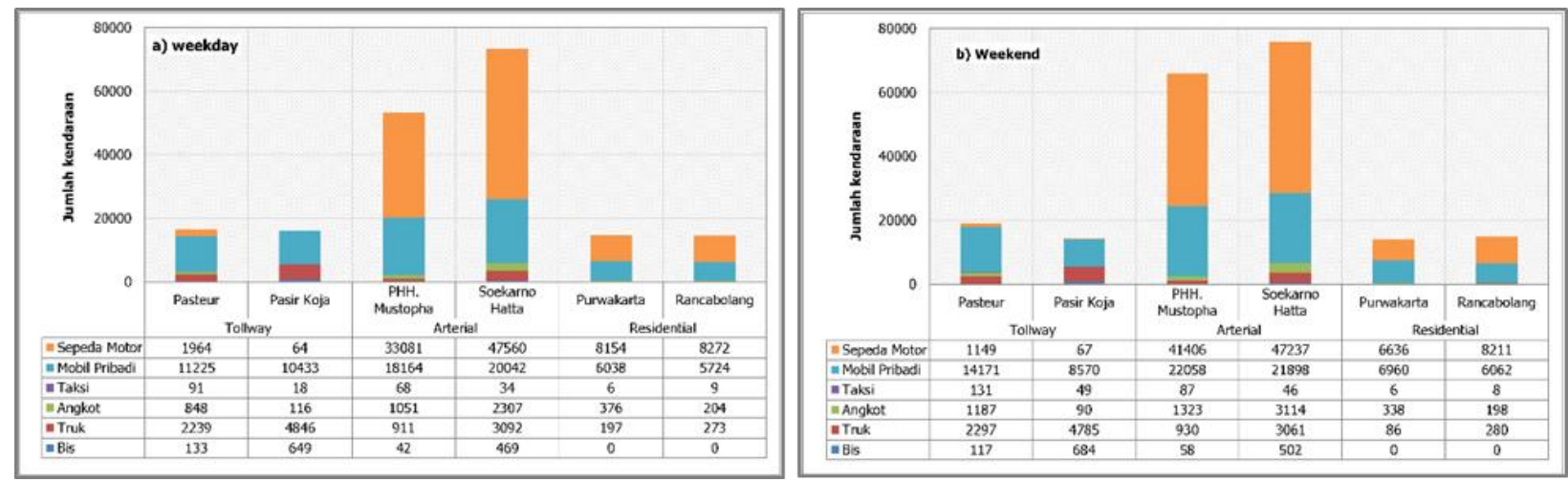

Gambar 2. Volume Kendaraan Bermotor Harian Kota Bandung Tahun 2019

Berdasarkan Gambar 2a dan $\mathbf{2 b}$, volume kendaraan bermotor total yang melintasi 3 (tiga) kategori jalan di Kota Bandung pada hari kerja (weekday) mencapai 188.700 unit dalam sehari. Jalan arterial meliputi jalan Soekarno Hatta dan PHH. Mustopha menjadi ruas jalan tersibuk, diikuti jalan tollway, dan jalan residential memiliki arus lalu lintas terendah. Sedangkan, pada hari libur (weekend) volume kendaraan bermotor total mencapai 203.802 unit kendaraan dalam sehari, lebih besar $52 \%$ dibandingkan pada hari kerja (weekday). Pola arus lalu lintas tersebut tidak jauh berbeda dari hari kerja, dimana jalan arterial masih menjadi jalan tersibuk, diikuti jalan tollway, dan jalan residential. Proporsi kendaraan bermotor yang mendominasi ruas-ruas jalan di Kota Bandung adalah mobil pribadi, sepeda motor, dan truk.

\subsection{Karakteristik Truk}

\subsubsection{Distribusi Teknologi Truk}

Fleet index merupakan nilai yang merepresentasikan distribusi penerapan teknologi pada jenis kendaraan bermotor tertentu khususnya truk. Berdasarkan hasil identifikasi teknologi diperoleh rincian fleet index truk di Kota Bandung tahun 2019 pada Tabel 4 berikut.

Tabel 4. Fleet Index Truk Kota Bandung

\begin{tabular}{ccccccc}
\hline Deskripisi & Fuel & Mesin & Exhaust & Age & Fleet Index & Index (\%) \\
\hline Auto/Sml Truck & Petrol & Carburetor & None & $80-161 \mathrm{~K} \mathrm{~km}$ & 1 & $3 \%$ \\
\hline Auto/Sml Truck & Petrol & Carburetor & None & $>161 \mathrm{~K} \mathrm{~km}$ & 2 & $2 \%$ \\
\hline Auto/Sml Truck & Petrol & Multi-Pt FI & none & $80-161 \mathrm{~K} \mathrm{~km}$ & 100 & $2 \%$ \\
\hline Auto/Sml Truck & Petrol & Multi-Pt FI & none & $>161 \mathrm{~K} \mathrm{~km}$ & 101 & $4 \%$ \\
\hline Auto/Sml Truck & Petrol & Multi-Pt FI & EuroII & $<79 \mathrm{~K} \mathrm{~km}$ & 180 & $13 \%$ \\
\hline Auto/Sml Truck & Petrol & Multi-Pt FI & EuroII & $80-161 \mathrm{~K} \mathrm{~km}$ & 181 & $8 \%$ \\
\hline Auto/Sml Truck & Petrol & Multi-Pt FI & EuroII & $>161 \mathrm{~K} \mathrm{~km}$ & 182 & $2 \%$ \\
\hline Auto/Sml Truck & Petrol & Multi-Pt FI & EuroII & $<79 \mathrm{~K} \mathrm{~km}$ & 183 & $2 \%$ \\
\hline Auto/Sml Truck & Petrol & Multi-Pt FI & EuroIV & $<79 \mathrm{~K} \mathrm{~km}$ & 198 & $1 \%$ \\
\hline Auto/Sml Truck & Diesel & Direct Injection & EGR+Improv & $80-161 \mathrm{~K} \mathrm{~km}$ & 760 & $4 \%$ \\
\hline Auto/Sml Truck & Diesel & Direct Injection & EGR+Improv & $>161 \mathrm{~K} \mathrm{~km}$ & 761 & $9 \%$ \\
\hline Truck/Bus & Diesel & Pre-Chamber Inject. & None & $>161 \mathrm{~K} \mathrm{~km}$ & 1076 & $1 \%$ \\
\hline Truck/Bus & Diesel & Pre-Chamber Inject. & None & $>161 \mathrm{~K} \mathrm{~km}$ & 1079 & $6 \%$ \\
\hline Truck/Bus & Diesel & Direct Injection & EGR+Improv & $80-161 \mathrm{~K} \mathrm{~km}$ & 1093 & $2 \%$ \\
\hline Truck/Bus & Diesel & Direct Injection & EGR+Improv & $>161 \mathrm{~K} \mathrm{~km}$ & 1094 & $3 \%$ \\
\hline Truck/Bus & Diesel & Direct Injection & EGR+Improv & $<79 \mathrm{~K} \mathrm{~km}$ & 1095 & $3 \%$ \\
\hline Truck/Bus & Diesel & Direct Injection & EGR+Improv & $80-161 \mathrm{~K} \mathrm{~km}$ & 1096 & $13 \%$ \\
\hline Truck/Bus & Diesel & Direct Injection & EGR+Improv & $>161 \mathrm{~K} \mathrm{~km}$ & 1097 & $21 \%$ \\
\hline Truck/Bus & Diesel & FI & EuroIV & $<79 \mathrm{~K} \mathrm{~km}$ & 1149 & $1 \%$ \\
\hline
\end{tabular}

Sumber : Hasil Analisis, 2019 
Berdasarkan Tabel 4, variasi distribusi penerapan teknologi truk di Kota Bandung direpresentasikan melalui fleet index yang mencapai 19 jenis dengan spesifikasi teknis yang beragam. Proporsi dominasi teknologi terbesar berasal dari index 1097 (21\%) yang merupakan heavy truk diesel dengan jarak tempuh >161K km, diikuti index 1096 (13\%) heavy truk diesel dengan jarak tempuh $80-161 \mathrm{~K} \mathrm{~km}$, dan index $180(13 \%)$ merupakan light truk petrol dengan jarak tempuh $<79 \mathrm{~K} \mathrm{~km}$.

\subsubsection{Aktivitas Berkendara Truk}

\section{A. Pola Kecepatan Harian Truk}

Data kecepatan per jam truk diperoleh dari hasil tracking aktivitas berkendara harian menggunakan GPS. Kecepatan rerata harian truk di Kota Bandung pada hari kerja sebesar $5,47 \mathrm{~km} / \mathrm{jam}$ dan hari libur $8,05 \mathrm{~km} / \mathrm{jam}$ dengan variasi harian kecepatan rerata per jam truk pada hari kerja selama 9 jam operasonal (08.00 AM-17.00 PM) berkisar 0,46 hingga 10,79 $\mathrm{km} / \mathrm{jam}$ dan untuk hari libur mencapai 3,69 hingga $11,09 \mathrm{~km} / \mathrm{jam}$ dengan waktu tempuh operasional selama 7 jam (08.00 AM-15.00 PM). Tingginya intensitas pergerakan truk di Kota Bandung pada akhir pekan dikarenakan sebagian besar truk di Kota Bandung hanya beroperasi selama setengah hari. Hal tersebut dipengaruhi oleh tingginya permintaan pengangkutan barang dengan lokasi yang cukup jauh dibandingkan pada hari kerja (lihat Gambar 2).

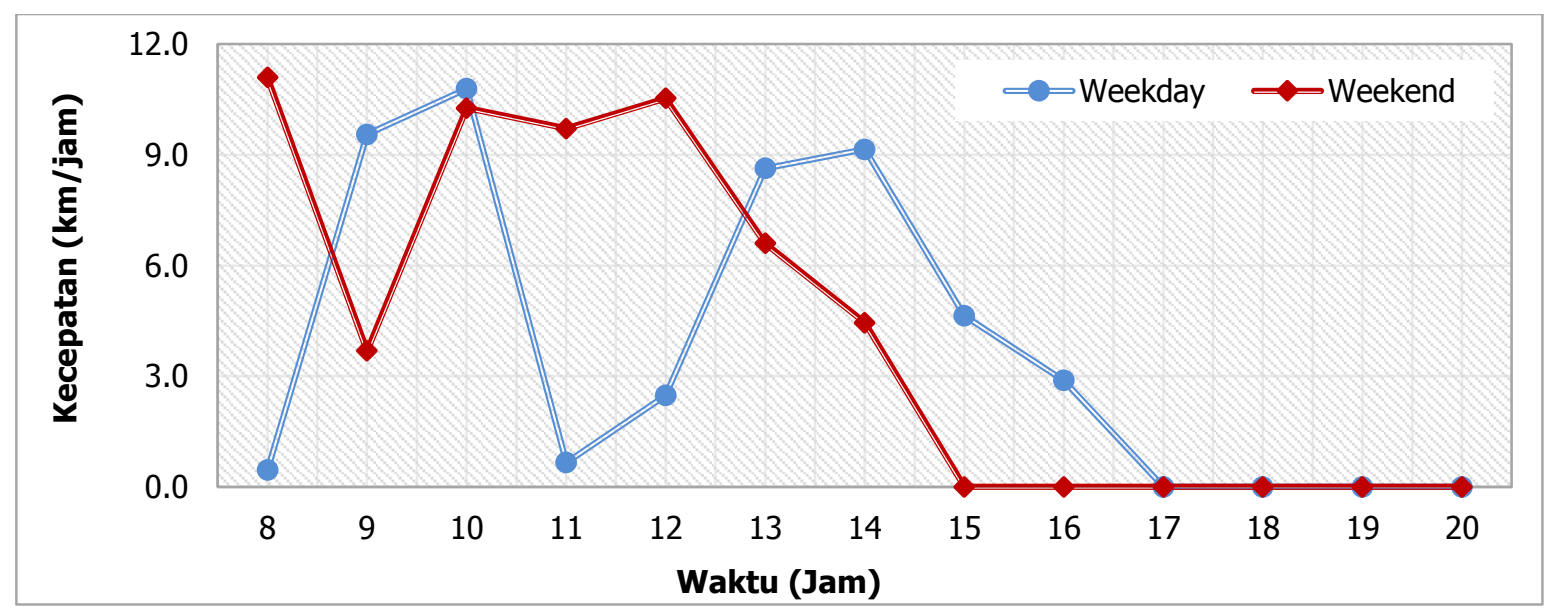

Gambar 2. Kecepatan Harian Truk Kota Bandung

B. Distribusi Soak Time Harian Truk

Soak time merupakan waktu jeda mesin kendaraan bermotor yang digunakan untuk mengidentifikasi jumlah start-up harian serta membedakan antara emisi cold start (idling $>18$ jam) dan warm start (idling<1 jam) yang terjadi selama operasional kendaraan bermotor. Berikut pada Gambar 3 merupakan akumulasi soak time harian truk di Kota Bandung. 


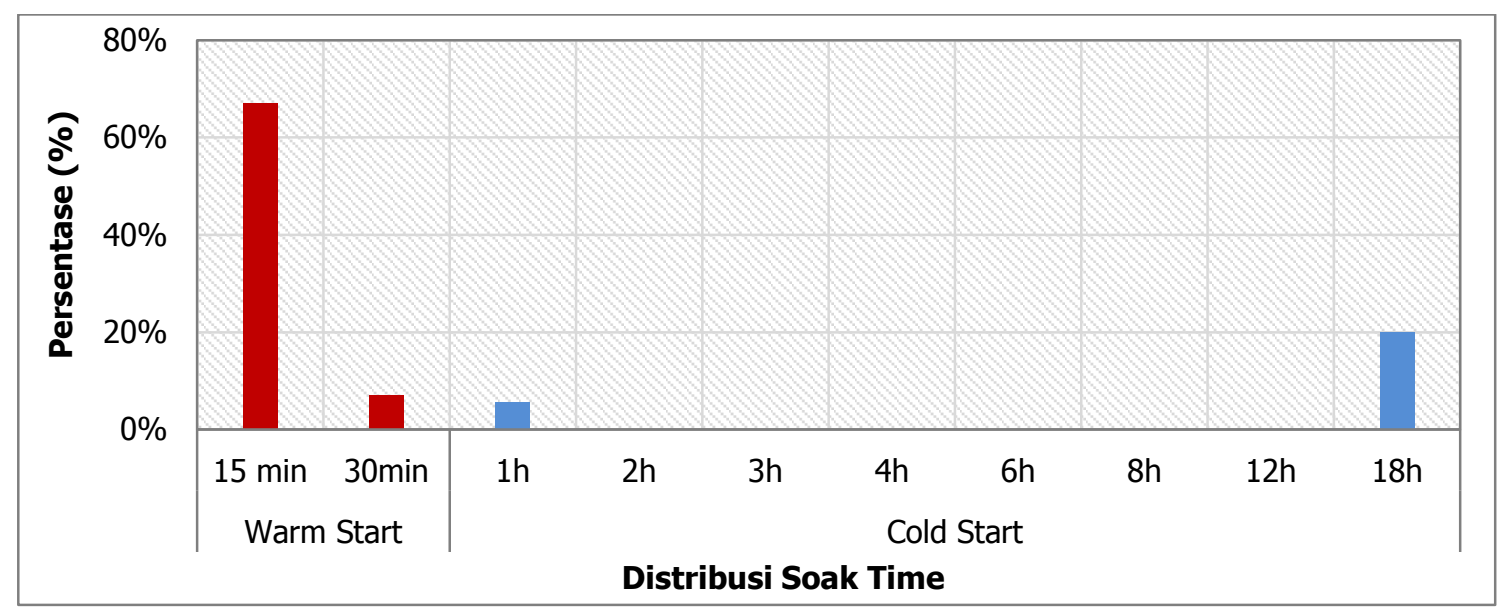

\section{Gambar 3. Distribusi Soak Time Truk Kota Bandung}

Berdasarkan hasil survei, mayoritas truk di Kota Bandung melakukan idling ketika tiba di tujuan pengangkutan barang dan jasa yakni tempat niaga. Selama operasional (lihat Gambar 3), rerata jumlah start-up harian truk di Kota Bandung mencapai 16x start/hari dengan 93\% mayoritas idling terjadi selama 15-30 menit (warm start). Sedangkan, sebagian kecil frekuensi truk melakukan idling selama 1 jam hingga 18 jam lamanya (cold start). Masifnya intensitas soak time pada periode yang singkat merupakan bentuk konsekuensi dari semakin tingginya kebutuhan pelaku ekonomi di Kota Bandung akan jasa pengangkutan dalam menunjang pergerakan ekonomi serta jarak tempuh yang relatif dekat antar tempat niaga yang menjadi salah satu faktor krusial lainnya.

C. Vehicle Kilometer Travelled (VKT) Harian Truk

Analisis regresi linier terhadap variable odometer dan umur aktual truk di Kota Bandung menampilkan nilai koefisien determinasi $\left(R^{2}\right)$ sebesar 0,97 . Hal tersebut mengindikasikan bahwa variabel umur sangat kuat mempengaruhi peningkatan jarak tempuh perjalanan truk di Kota Bandung (lihat Gambar 4).

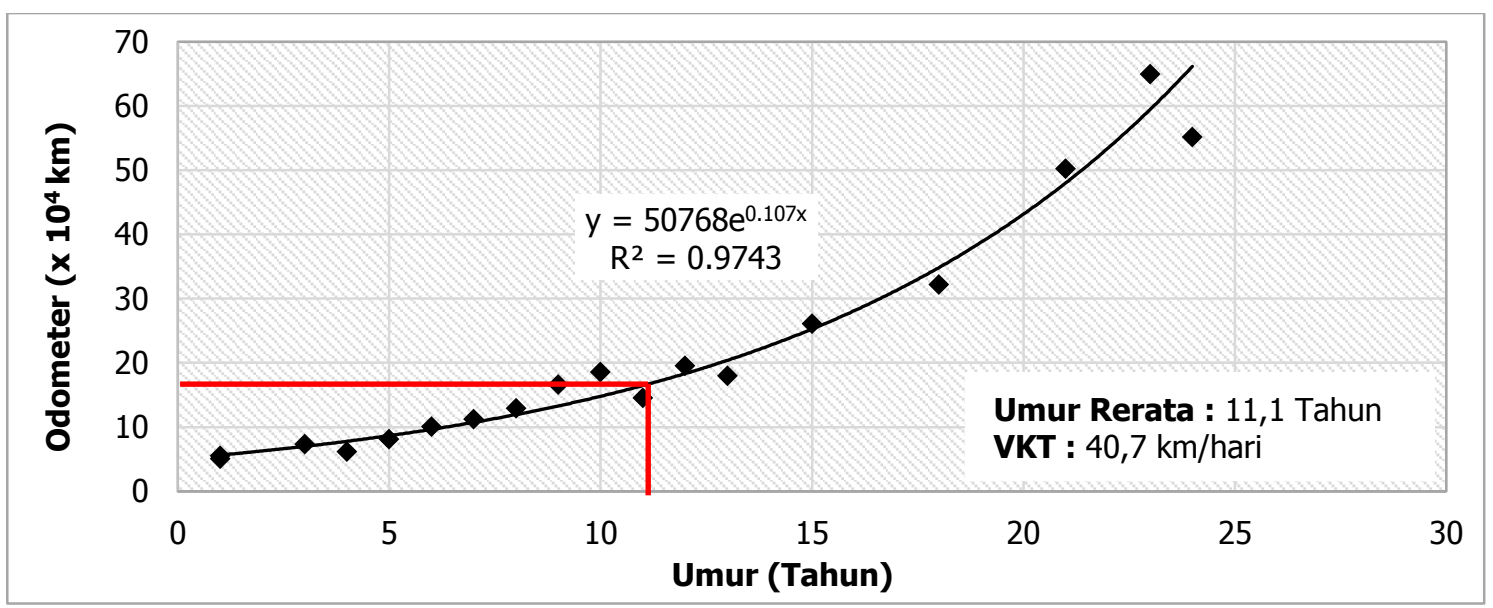

Gambar 4. Vehicle Killometer Travelled (VKT) Harian Truk Kota Bandung

Hasil identifikasi tersebut akan digunakan sebagai pertimbangan dalam memperkirakan VKT harian truk di Kota Bandung, sehingga diperoleh rerata panjang perjalanan harian mencapai $40,7 \mathrm{~km} / \mathrm{hari}$. 
D. Distribusi Nilai Bin Vehicle Specific Power (VSP)

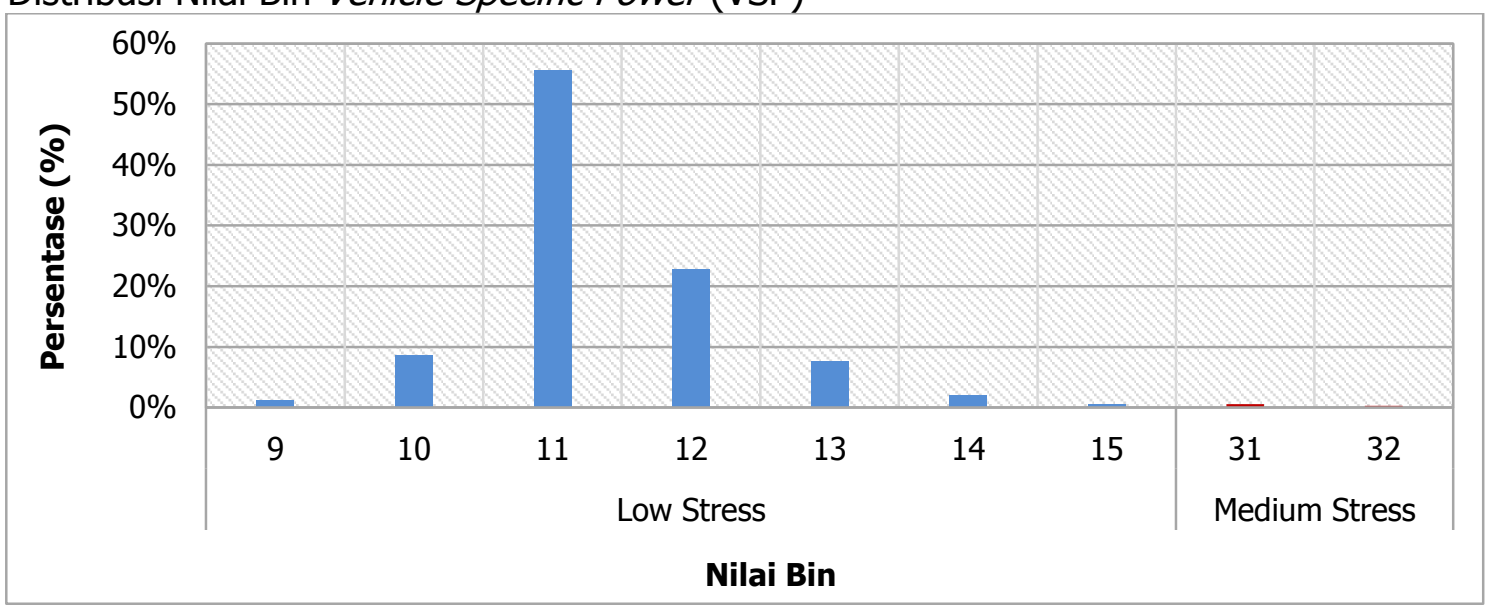

\section{Gambar 5. Distribusi VSP Bin Truk Kota Bandung}

Berdasarkan Gambar 5, mayoritas distribusi VSP bin truk di Kota Bandung diamati berada kondisi tegangan mesin rendah (low stress) pada nilai bin 11 (VSP $=-2,9$ hingga $1,2 \mathrm{~kW} / \mathrm{t}$ ) dengan kontribusi 55,57\%, dan 22,81\% dari bin 12 (VSP $=1,2$ hingga 5,3 kW/t). Hal ini terjadi ketika truk beroperasi pada kecepatan dan putaran mesin rendah dan kurang akselerasi yang ditandai melalui sering berhentinya truk dalam kondisi macet, dan idling selama unloading barang. Sedangkan, jarangnya aktivitas berkendara truk terjadi pada kecepatan dan percepatan konstan cenderung menimbulkan tegangan mesin sedang (medium stress) dengan nilai bin yang lebih tinggi.

\subsection{Faktor Emisi Komposit Truk}

Faktor emisi local komposit truk di Kota Bandung diperoleh melalui hasil pemodelan menggunakan model International Vehicle Emissions (IVE). Adapun rincian selengkapnya dapat dilihat pada Tabel $\mathbf{4}$ sebagai berikut.

Tabel 4. Faktor Emisi Komposit Truk Kota Bandung

\begin{tabular}{ccc}
\hline \multirow{2}{*}{ Polutan } & \multicolumn{2}{c}{ Faktor Emisi Komposit } \\
\cline { 2 - 3 } & Start-up (g/start) & Running (g/km) \\
\hline $\mathrm{CO}$ & 3,522 & 16,693 \\
\hline $\mathrm{NO}_{x}$ & 0,547 & 12,211 \\
\hline $\mathrm{SO}_{x}$ & 0,002 & 0,135 \\
\hline $\mathrm{PM}$ & 2,007 & 5,982 \\
\hline $\mathrm{CO}_{2}$ & 15,397 & 1330,794 \\
\hline $\mathrm{N}_{2} \mathrm{O}$ & 0,001 & 0,015 \\
\hline $\mathrm{CH}_{4}$ & 0,067 & 0,375 \\
\hline
\end{tabular}

Sumber : Hasil Analisis, 2019

Berdasarkan perbandingan faktor emisi komposit pada Tabel $\mathbf{3}$ dan $\mathbf{5}$, kendaraan bermesin diesel khususnya truk menghasilkan nilai faktor emisi $\mathrm{CO}_{2}, \mathrm{NO}_{x}$ dan $\mathrm{PM}$ lebih besar dibandingkan kendaraan bermesin petrol. Sebaliknya, kendaraan bermesin petrol menghasilkan nilai faktor emisi CO lebih besar. Dominasi penerapan mesin diesel yang memiliki kapasitas yang besar sehingga membutuhkan bahan bakar dalam jumlah yang besar disertai dengan komposisi bahan bakar diesel memiliki konsentrasi karbon yang lebih tinggi dibandingkan petrol dan usia truk yang tua di Kota Bandung menjadi faktor penyebab nilai faktor emisi $\mathrm{PM}, \mathrm{NO}_{x}$, dan $\mathrm{CO}_{2}$ yang tinggi. Sedangkan, rendahnya faktor emisi $\mathrm{CO}$ pada mesin diesel disebabkan oleh efisiensi thermal dalam melakukan pembakaran bahan bakar 
pada internal mesin lebih efektif sehingga terjadi secara sempurna (Soenarto dan Furuhama, 1985).

\subsection{Beban Emisi}

\subsubsection{Emisi Start-up}

Hasil perhitungan model IVE untuk beban emisi start-up kendaraan bermotor di Kota Bandung dapat dilihat pada Gambar 6 sebagai berikut.

\begin{tabular}{|c|c|c|c|c|c|c|c|}
\hline \multirow{2}{*}{ 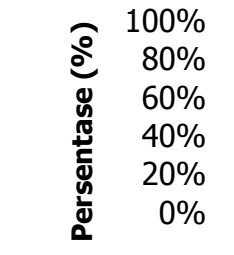 } & & & & & & & \\
\hline & $\mathrm{CO}$ & NOx & SOx & PM & $\mathrm{CO} 2$ & $\mathrm{~N} 2 \mathrm{O}$ & $\mathrm{CH} 4$ \\
\hline Sepeda Motor & 19346.4 & 1696.5 & 0.8 & 167.8 & 8119.5 & 2.4 & 2.4 \\
\hline Mobil Pribadi & 12372.8 & 478.3 & 2.6 & 34.1 & 8455.6 & 2.9 & 297.0 \\
\hline - Taksi & 85.2 & 5.1 & 0.0 & 0.1 & 54.3 & 0.0 & 1.7 \\
\hline Angkot & 172.1 & 7.0 & 0.0 & 0.5 & 106.1 & 0.0 & 3.3 \\
\hline Bus & 13.0 & 32.6 & 0.4 & 53.0 & 1100.2 & 0.4 & 0.0 \\
\hline a Truk & 1523.1 & 236.8 & 0.8 & 868.2 & 6659.3 & 0.5 & 29.2 \\
\hline
\end{tabular}

Gambar 6. Beban Emisi Start-up (Ton/Tahun) Kendaraan Bemotor Kota Bandung

Emisi total kendaraan bermotor di Kota Bandung tahun 2019 paling dominan dihasilkan pada kondisi start-up yakni parameter CO sebesar $54,11 \%$ setara $33.512,52$ ton/tahun, diikuti $\mathrm{CO}_{2}$ sebesar 39,55\% setara 24.494,93 ton/tahun, dan $\mathrm{NO}_{x}$ sebesar 3,97\% setara $2.456,13$ ton/tahun. Proporsi emisi start-up terbesar di Kota Bandung berasal dari 47,4\% sepeda motor, 34,9\% mobil pribadi dan 15\% merupakan emisi truk yang dipengaruhi oleh tingginya tingkat populasi kendaraan bermotor tersebut di Kota Bandung.

Tingginya kontribusi emisi total CO pada kondisi start-up disebabkan oleh kinerja mesin pasca idling cenderung belum maksimal untuk menciptakan kondisi panas (suhu) dan tekanan yang tinggi di dalam ruang bakar mesin sehingga menyebabkan pembakaran bahan bakar tidak terjadi secara sempurna (Rosid, 2016). Kontribusi emisi $\mathrm{CO}_{2}$ pada kondisi startup terbesar kedua setelah $\mathrm{CO}$, berasal dari sebagian kecil proses pembakaran telah mencapai kondisi sempurna selama periode kompresi mesin. Sementara itu, rendahnya kontribusi $\mathrm{NO}_{\mathrm{x}}$ disebabkan oleh belum terlalu maksimalnya kinerja mesin untuk mencapai panas (suhu) dan tekanan yang tinggi pada ruang bakar mesin (Soenarto dan Furuhama, 1985). Selain itu, masih cukup dominannya proporsi pre-euro menjadi salah satu alasan masih tingginya emisi kendaraan bermotor di Kota Bandung.

\subsubsection{Emisi Running}

Hasil perhitungan model IVE untuk beban emisi running kendaraan bermotor di Kota Bandung dapat dilihat pada Gambar 7 sebagai berikut. 


\begin{tabular}{|c|c|c|c|c|c|c|c|}
\hline \multirow[t]{2}{*}{ 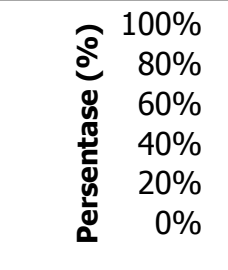 } & & & & & & & \\
\hline & $\mathrm{CO}$ & NOx & SOx & PM & $\mathrm{CO} 2$ & $\mathrm{~N} 2 \mathrm{O}$ & $\mathrm{CH} 4$ \\
\hline - Sepeda Motor & 77479.7 & 2061.3 & 74.9 & 411.2 & 841272.1 & 0.0 & 4971.3 \\
\hline Mobil Pribadi & 117440.2 & 9389.6 & 283.3 & 193.7 & 2278931.3 & 58.1 & 2255.6 \\
\hline - Taksi & 810.3 & 38.6 & 1.1 & 0.3 & 10164.1 & 0.3 & 18.9 \\
\hline Angkot & 4606.7 & 352.1 & 10.8 & 7.1 & 74417.3 & 1.8 & 106.4 \\
\hline Bus & 1646.6 & 7390.7 & 200.9 & 1442.4 & 551956.4 & 26.3 & 0.0 \\
\hline - Truk & 18882.9 & 13813.2 & 152.9 & 6766.4 & 1505376.7 & 16.6 & 424.4 \\
\hline
\end{tabular}

Gambar 7. Beban Emisi Running (Ton/Tahun) Kendaraan Bemotor Kota Bandung

Berdasarkan Gambar 7, kondisi emisi total kendaraan bermotor di Kota Bandung tahun 2019 pada saat running mengalami peningkatan dari aspek kuantitas dan perubahan strata kontribusi emisi. Emisi $\mathrm{CO}_{2}$ menjadi kontributor terbesar dengan 95,1\% setara 5.262.117,87 ton/tahun, diikuti CO sebesar 3,99\% setara 220.866,38 ton/tahun, dan $\mathrm{NO}_{x}$ sebesar $0,60 \%$ setara 33.045,52 ton/tahun. Proporsi emisi running terbesar di Kota Bandung berasal dari $43,5 \%$ mobil pribadi, diikuti $27,9 \%$ truk, $16,7 \%$ sepeda motor, dan $10,2 \%$ bus. Peningkatan signifikan pada truk dan bus sebesar disebabkan oleh efisiensi thermal pada mesin diesel sudah tercapai maksimal sehingga proses pembakaran bahan bakar dapat terjadi secara sempurna (Gunadarma, 2019).

Tingginya kontribusi emisi running total karbon dioksida $\left(\mathrm{CO}_{2}\right)$ disebabkan oleh kinerja mesin selama operasional berada pada intensitas putaran rendah hingga menengah sehingga memicu tercapainya kondisi panas dan tekanan yang tinggi pada ruang pembakaran mesin untuk melakukan pembakaran bahan bakar secara sempurna (Soenarto dan Furuhama, 1985). Oleh karena itu, kandungan HC pada bahan bakar sangat mudah teroksidasi menjadi karbon dioksida $\left(\mathrm{CO}_{2}\right)$ disertai pasokan $\mathrm{O} 2$ yang berlimpah (Godish, 2004). Sebaliknya, emisi CO running terbentuk pada kondisi tegangan mesin cukup rendah (low stress) yang ditandai dengan kecepatan, putaran mesin dan akselerasi menurun. Hal tersebut memicu terjadinya pembakaran tidak sepenuhnya sempurna sehingga masih menyisakan senyawa CO yang tidak teroksidasi menjadi $\mathrm{CO}_{2}$ (Godish, 2004). Emisi $\mathrm{NO}_{x}$ running mengalami peningkatan signifikan sebesar 32\% dibandingkan emisi $\mathrm{NO}_{x}$ start-up. Hal ini dikarenakan panas (suhu) dan tekanan ideal pada ruang bakar mesin sudah maksimal untuk membentuk senyawa $\mathrm{NO}_{\mathrm{x}}$ (Flagan dan Seinfeld, 1988). Sementara itu, emisi PM mengalami peningkatan signifikan pada kondisi running yang disebabkan oleh tingginya faktor emisi PM yang disertai dengan peningkatan kinerja mesin diesel pada truk dan bus. Peningkatan tersebut dapat menghasilkan emisi PM lebih banyak yang merupakan residu senyawa karbon pada bahan bakar diesel yang tidak ikut terbakar dalam ruang bakar mesin (Flagan dan Seinfeld, 1988; Rosid, 2016).

\subsubsection{Emisi Total}

Beban emisi total merupakan hasil penjumlahan antara emisi start-up dengan running dari setiap polutan yang diteliti untuk setiap jenis kendaraan bermotor tertentu. Rincian selengkapnya dapat dilihat pada Gambar 8 dibawah ini. 


\begin{tabular}{|c|c|c|c|c|c|c|c|}
\hline \multirow[t]{2}{*}{ 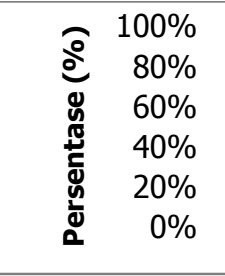 } & & & & & & & \\
\hline & $\mathrm{CO}$ & NOx & SOx & PM & $\mathrm{CO} 2$ & $\mathrm{~N} 2 \mathrm{O}$ & $\mathrm{CH} 4$ \\
\hline Sepeda Motor & 96826.03 & 3757.81 & 75.66 & 578.92 & 849391.59 & 2.36 & 4973.66 \\
\hline Mobil Pribadi & 129812.95 & 9867.92 & 285.81 & 227.73 & 2287386.92 & 60.92 & 2552.65 \\
\hline - Taksi & 895.53 & 43.65 & 1.16 & 0.39 & 10218.42 & 0.27 & 20.61 \\
\hline Angkot & 4778.77 & 359.05 & 10.85 & 7.59 & 74523.37 & 1.82 & 109.71 \\
\hline Bus & 1659.54 & 7423.22 & 201.34 & 1495.31 & 553056.55 & 26.66 & 0 \\
\hline Truk & 20406.09 & 14050 & 153.65 & 7634.62 & 1512035.96 & 17.11 & 453.59 \\
\hline
\end{tabular}

Gambar 8. Beban Emisi Total (Ton/Tahun) Kendaraan Bemotor Kota Bandung

Berdasarkan Gambar 8, terdapat 3 (tiga) parameter polutan yang mendominasi emisi total kendaraan bermotor di Kota Bandung diantaranya karbon dioksida $\left(\mathrm{CO}_{2}\right)$ menjadi kontributor terbesar dengan $94,48 \%$ setara $5.286 .612,81$ ton/tahun, karbon monoksida (CO) $4,55 \%$ setara 25434.378,9 ton/tahun dan oksida nitrogen (NOx) 0,63\% setara 35.501,65 ton/tahun. Parameter emisi tersebut merupakan hasil pembakaran internal mesin kendaraan bermotor yang paling umum diproduksi (Godish, 2004).

Mayoritas emisi total kendaraan bermotor di Kota Bandung berasal dari kondisi running dengan kontribusi total sebesar $98,9 \%$ setara dengan 5.533.454,28 ton/tahun untuk setiap polutan dan kendaraan bermotor yang diteliti. Sedangkan, kondisi start-up berkontribusi atas $1,07 \%$ emisi total setara dengan $61.931,47$ ton/tahun untuk setiap polutan dan kendaraan bermotor yang diteliti. Tingginya dominasi tersebut dikarenakan periode waktu running terjadi dalam momen yang panjang yakni selama fase operasional dalam sehari penuh. Oleh karena itu, pada kondisi running mesin cenderung sudah mencapai fase kinerja maksimal sehingga mendukung berlangsungya proses pembakaran secara sempurna (Soenarto dan Furuhama, 1985). Sebaliknya, periode waktu start-up hanya dapat dilakukan pada momen tertentu yang cenderung singkat sehingga fase kinerja mesin belum mencapai titik maksimalnya untuk melakukan proses pembakaran secara sempurna yang berimbas pada tingginya emisi CO.

\section{KESIMPULAN}

Berdasarkan hasil estimasi model International Vehicle Emissions (IVE) dapat disimpulkan bahwa emisi total kendaraan bermotor di Kota Bandung paling dominan berasal dari $94,48 \%$ setara 5.286.612,81 ton/tahun $\mathrm{CO}_{2}, 4,55 \%$ setara $25434.378,9$ ton/tahun $\mathrm{CO}$, dan 0,63\% setara 35.501,65 ton/tahun $\mathrm{NO}_{\mathrm{x}}$. Sedangkan, parameter emisi lainnya $\left(\mathrm{PM}, \mathrm{SO}_{\mathrm{x}} \mathrm{CH}_{4}\right.$, dan $\mathrm{N}_{2} \mathrm{O}$ ) hanya berkontribusi rerata $<0,5 \%$ dari total emisi yang dihasilkan. Emisi total tersebut hampir 98,9\% setara 5.533.454,28 ton/tahun berasal dari kondisi running dan hanya 1,07\% setara $61.931,47$ ton/tahun berasal dari kondisi start-up. Jika ditinjau dari kontribusi setiap jenis kendaraan bermotor terhadap emisi total setiap polutan di Kota Bandung, maka yang paling mendominasi adalah $43,4 \%$ mobil pribadi, diikuti $27,8 \%$ truk, $17,1 \%$ sepeda motor, dan $10,1 \%$ berasal dari bus. Sementara itu, angkot dan taksi berkontribusi sangat minim < $2 \%$ terhadap total emisi yang dihasilkan. 


\section{DAFTAR RUJUKAN}

Asian Development Bank. (2019). Asian Development Outlook 2019 Update : Fostering Growth and Inclusion in Asia'a Cities. Retrieved from https://www.adb.org/publications/asian-development-outlook-2019-update

Badan Pusat Statistik. (2018). Kota Bandung Dalam Angka 2018. Bandung: BPS Kota Bandung.

Davis, N. (2008). International Vehicle Emission (IVE) Model User Manual Version 2.0 USA: ISSRC.

Flagan, R. C., dan Seinfeld, J. H. (1988). Fundamentals of Air Pollution Engineering. New Jersey: Prentice Hall.

Godish, T. (2004). Air Quality (4th Edition ed.). United States of America: Lewis Publisher.

Gunadarma, A. K. (2019). Hal yang Menyebabkan Mesin Diesel Cepat Panas. Retrieved from http://fastnlow.net/hal-yang-menyebabkan-mesin-diesel-cepat-panas/

Kementerian Lingkungan Hidup. (2012). Petunjuk Teknis Dekonsentrasi Pengendalian Pencemaran Udara Sumber Bergerak. Jakarta.

Oanh, N. T. K., Permadi, D. A., Huy, L. N., Zusman, E., Nakano, R., Nugroho, S. B., Lestari, P., dan Sofyan, A. (2018). Assesment of Urban Passenger Fleet Emissions to Quantify Climate and Air Quality Co-Benefits Resulting from Potential Interventions. Carbon Management Journal, 09, 367-381.

Peraturan Pemerintah 26 Tahun 2008 tentang Rencana Tata Ruang Wilayah Nasional (RTRWN).

Rosid. (2016). Analisa Proses Pembakaran pada Motor Bensin 113.5 cc dengan Simulasi ANSYS. Jurnal Teknologi, Volume 08.

Soenarto, N., dan Furuhama, S. (1985). Motor Serbaguna. Jakarta: PT. Pradnya Paramita. 